This item was submitted to Loughborough's Research Repository by the author.

Items in Figshare are protected by copyright, with all rights reserved, unless otherwise indicated.

\title{
Optical optimization of high resistance transparent layers in thin film cadmium telluride solar cells
}

PLEASE CITE THE PUBLISHED VERSION

http://dx.doi.org/10.1016/j.vacuum.2016.11.031

PUBLISHER

(C) Elsevier

VERSION

AM (Accepted Manuscript)

\section{PUBLISHER STATEMENT}

This work is made available according to the conditions of the Creative Commons Attribution-NonCommercialNoDerivatives 4.0 International (CC BY-NC-ND 4.0) licence. Full details of this licence are available at: https://creativecommons.org/licenses/by-nc-nd/4.0/

\section{LICENCE}

CC BY-NC-ND 4.0

\section{REPOSITORY RECORD}

Womack, Gerald, Piotr M. Kaminski, and Michael Walls. 2019. "Optical Optimization of High Resistance Transparent Layers in Thin Film Cadmium Telluride Solar Cells". figshare. https://hdl.handle.net/2134/23529. 


\title{
Optical Optimization of High Resistance Transparent Layers
}

\section{in Thin Film Cadmium Telluride Solar Cells}

\author{
${ }^{1,2}$ G. Womack, ${ }^{1}$ P.M. Kaminski*, ${ }^{1}$ J.M. Walls
}

\begin{abstract}
${ }^{1}$ CREST (Centre for Renewable Energy Systems Technology), Wolfson School of Mechanical, Electrical and Manufacturing Engineering, Loughborough University, Loughborough, LE11 3TU, United Kingdom
\end{abstract}

${ }^{2}$ National Structural Integrity Research Centre (NSIRC Ltd.), Granta Park, Great Abington, Cambridge, CB21 6AL, United Kingdom

*Corresponding author: g.womack@lboro.ac.uk

Abstract

Thin film photovoltaic devices are multilayer opto-electrical structures in which light interference occurs. Light reflection at the interfaces and absorption within the window layers reduces transmission and, ultimately, the conversion efficiency of photovoltaic devices. Optical reflection losses can be reduced by adjusting the layer thicknesses to achieve destructive interference within the structure of the cell. The light transmission to the CdTe absorber of a CdS/CdTe cell on a fluorine doped tin oxide transparent conductor has been modeled using the transfer matrix method. The interference effect in the $\mathrm{CdS}$ layer and high resistance transparent buffer layers $\left(\mathrm{SnO}_{2}\right.$ and $\left.\mathrm{ZnO}\right)$ has been investigated. The modeling shows that due to relatively high absorption within the $\mathrm{SnO}_{2}$ layer, there are modest benefits to engineering anti-reflection interference in the stack. However, a $\mathrm{ZnO}$ buffer layer has limited absorption and interference can be exploited to provide useful anti-reflection effects. Optical modeling and 
optimization shows that for a $50 \mathrm{~nm} \mathrm{CdS}$ layer, a maximum transmission of $78.5 \%$ is possible using $\mathrm{ZnO}$ as a buffer layer at $58 \mathrm{~nm}$ thickness, and $78.0 \%$ for a $\mathrm{SnO}_{2}$ buffer layer at a thickness of $48 \mathrm{~nm}$.

Keywords: Thin film, Optical interference, Anti-reflection Coating, CdTe, Solar cell, Conversion efficiency, High Resistance Transparent layer.

\section{Introduction}

Thin film CdTe solar cells have achieved commercial success through low manufacturing costs and increasingly high efficiencies. Energy conversion efficiencies of $22.1 \%$ have been reported for thin film CdTe solar cells [1]. However, the theoretical efficiency limit for this type of device is $\sim 30 \%$ [2]. Both optical and electrical losses occur in CdTe solar cells. Electrical losses are normally of greater magnitude than optical losses, but if light fails to reach the active layer of the stack, a photocurrent is not generated. As such, optical losses precede electrical losses, imposing limitations on photocurrent if not addressed. The losses occur due to reflection and light absorption in layers which do not contribute to the photocurrent, such as the CdS window layer [3].

Light interference effects occur in the multilayer structure of the cell. The reflection losses can be controlled and reduced by tuning the thickness of individual layers to achieve an interference minimum. The absorption losses in the window layer can be reduced by thinning the window layer thickness, which usually requires use of a high resistance transparent layer to prevent voltage and shunt losses [4]. Optical modelling has been used to assess the optical losses within the CdTe solar stack in a simpler model [5], and to evaluate internal reflection losses in a-Si solar cells [6]. In this work, optical modeling was used to investigate how optimizing the various layer thicknesses can increase light transmission to the CdTe absorber layer to increase the photocurrent generated.

\subsubsection{The thin film CdTe solar cell}

The CdTe solar cell is a thin film stack with a total thickness typically $\sim 3 \mu \mathrm{m}$. For commercial modules, the layers are deposited on to a low cost soda lime glass substrate coated with a transparent conducting 
oxide (TCO). NSG Pilkington TEC glass is an industrial standard substrate. The TEC glass consists of $\mathrm{SnO}_{2}, \mathrm{SiO}_{2}$ and $\mathrm{SnO}_{2}: \mathrm{F}$ layers deposited on $3.2 \mathrm{~mm}$ thick float glass. Depending on the properties required, there are different types of TEC glass characterized by different light transmission, sheet resistance, and surface roughness. TEC 10 glass is an option for CdTe solar cells. The glass is characterized by $70 \%$ light transmission in the AM1.5 solar spectrum and a $9 \Omega / \square$ sheet resistance [7].

The CdTe solar cell is deposited onto a TCO coated glass. A simple cell structure consists of CdSCdTe hetero-junction and a back contact. The CdS layer is usually $\sim 100 \mathrm{~nm}$ thick. The CdS acts as an ntype semiconductor and enables the photovoltaic effect in the solar cell. The band-gap of $\mathrm{CdS}$ is $2.4 \mathrm{eV}$ which corresponds to an absorption edge at $\sim 500 \mathrm{~nm}$. The photons absorbed in the window layer do not contribute to the photocurrent of the solar cell, as recombination is very likely to occur, resulting in scattering of light. Therefore, absorption in the CdS layer is a source of significant loss. In a typical cell utilizing CdS, the photocurrent is limited to $22-23 \mathrm{~mA} / \mathrm{cm}^{2}$, although $31 \mathrm{~mA} / \mathrm{cm}^{2}$ is available in the spectrum utilized by CdTe absorber [8], [9].

$\mathrm{CdTe}$ is a semiconductor material with a band-gap of $1.45 \mathrm{eV}$ which corresponds to an $850 \mathrm{~nm}$ absorption edge. Soda lime glass absorbs light at wavelengths of 350nm and below [10]. Optically, therefore, the CdTe device absorbs wavelengths between 350nm and 850nm.

The ideal refractive index of a typical single layer anti-reflection coating is the product of the refractive indices of the materials at the media interface, square rooted [11](equation 1).

$$
n_{c}=\sqrt{n_{0} n_{1}}
$$

In equation $1, n_{c}$ is the refractive index of the coating, $n_{0}$ is the refractive index of the incident material, and $n_{1}$ is the refractive index of the substrate material. 


\subsubsection{High resistance transparent (HRT) buffer layers}

High resistance transparent buffer layers have been shown to improve solar cell efficiencies by reducing the necessary thickness of the CdS layer and reducing shorting through the CdS layer [12], [13]. The buffer layer is located between the CdS layer and the fluorine doped tin oxide TCO layer. The refractive indices are 1.9 and 2.5 respectively, at the maximum in the AM1.5 spectrum $~ 550 \mathrm{~nm}$ wavelength. Using equation 2 , the ideal refractive index to maximize transmission at a wavelength of $550 \mathrm{~nm}$ is $\sim 2.2$. The refractive indices of $\mathrm{ZnO}$ and $\mathrm{SnO}_{2}$ are 2.0 and 1.9 respectively. As the refractive index of $\mathrm{ZnO}$ is closer to that of an ideal anti-reflection layer in the $350 \mathrm{~nm}$ to $850 \mathrm{~nm}$ region, the destructive interference of reflections from different interfaces within the system is more complete. This results in lower reflection minima when $\mathrm{ZnO}$ is implemented as the buffer layer.

Bulk $\mathrm{SnO}_{2}$ is a transparent n-type semiconductor with a band-gap of $3.6 \mathrm{eV}$ and a refractive index of $\sim 1.9$ at 550nm [14], [15]. Thin film $\mathrm{SnO}_{2}$ has been used as a HRT buffer layer in CdTe solar cells at a variety of thicknesses between $12.5 \mathrm{~nm}$ and 100nm [16]. Figure 1 shows the structure of a thin film CdTe solar cell incorporating an HRT buffer layer. It has been shown that the inclusion of a $\mathrm{SnO}_{2} \mathrm{HRT}_{\text {buffer }}$ layer in a standard CdTe/CdS solar cell, with Fluorine doped tin oxide transparent conducting oxide, leads to a $90 \mathrm{mV}$ improvement to open-circuit voltage (Voc) and a $6 \%$ improvement in Fill Factor [16]. The inclusion of a $\mathrm{SnO}_{2}$ HRT_buffer layer has a negligible effect on spectral response and Jsc, whilst raising the shunt resistance of the device [16].

An alternative HRT buffer layer material to $\mathrm{SnO}_{2}$ is $\mathrm{Zinc}$ Oxide $(\mathrm{ZnO})$. The refractive index of $\mathrm{ZnO}$ at $550 \mathrm{~nm}$ is $\sim 2.0$ and the band-gap of $\mathrm{ZnO}$ is $\sim 3.3 \mathrm{eV}$ [17]. $\mathrm{ZnO}$ has been modeled previously as a HRT buffer layer in CdTe solar cells using a thickness of $115 \mathrm{~nm}$ [18]. The addition of a ZnO HRT buffer layer has been shown to be beneficial to $\mathrm{CdS} / \mathrm{CdTe}$ solar cell efficiency [19]. ZnO has also been used as a HRT buffer layer in $\mathrm{Cu}(\mathrm{InGa}) \mathrm{Se}_{2}$ (CIGS) solar cell devices [20].

The dispersion relationships and absorption coefficients of $\mathrm{SnO}_{2}$ and $\mathrm{ZnO}$ are shown in figures 2 and 3 respectively. 


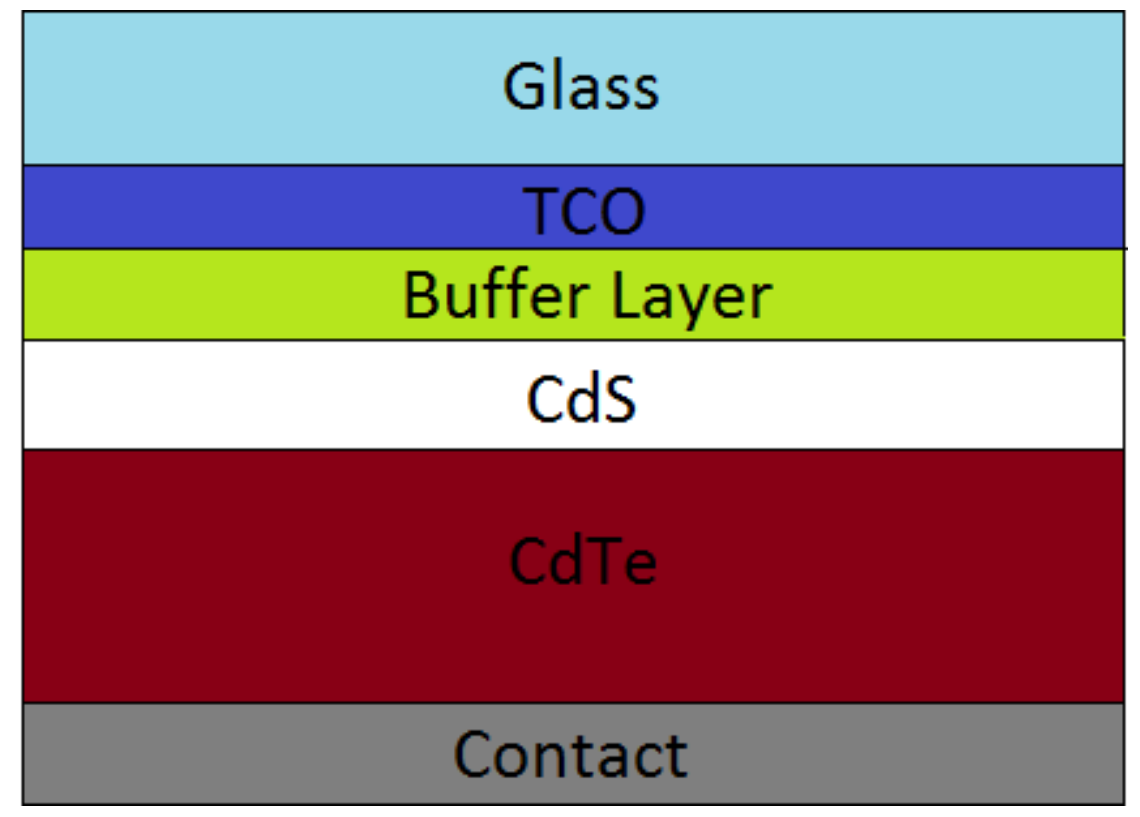

Figure 1 A schematic diagram of the CdTe solar cell structure showing the position of (from bottom to the top), the back contact, the CdTe absorber, the CdS window layer, the buffer layer, the TCO layer, and the glass substrate.

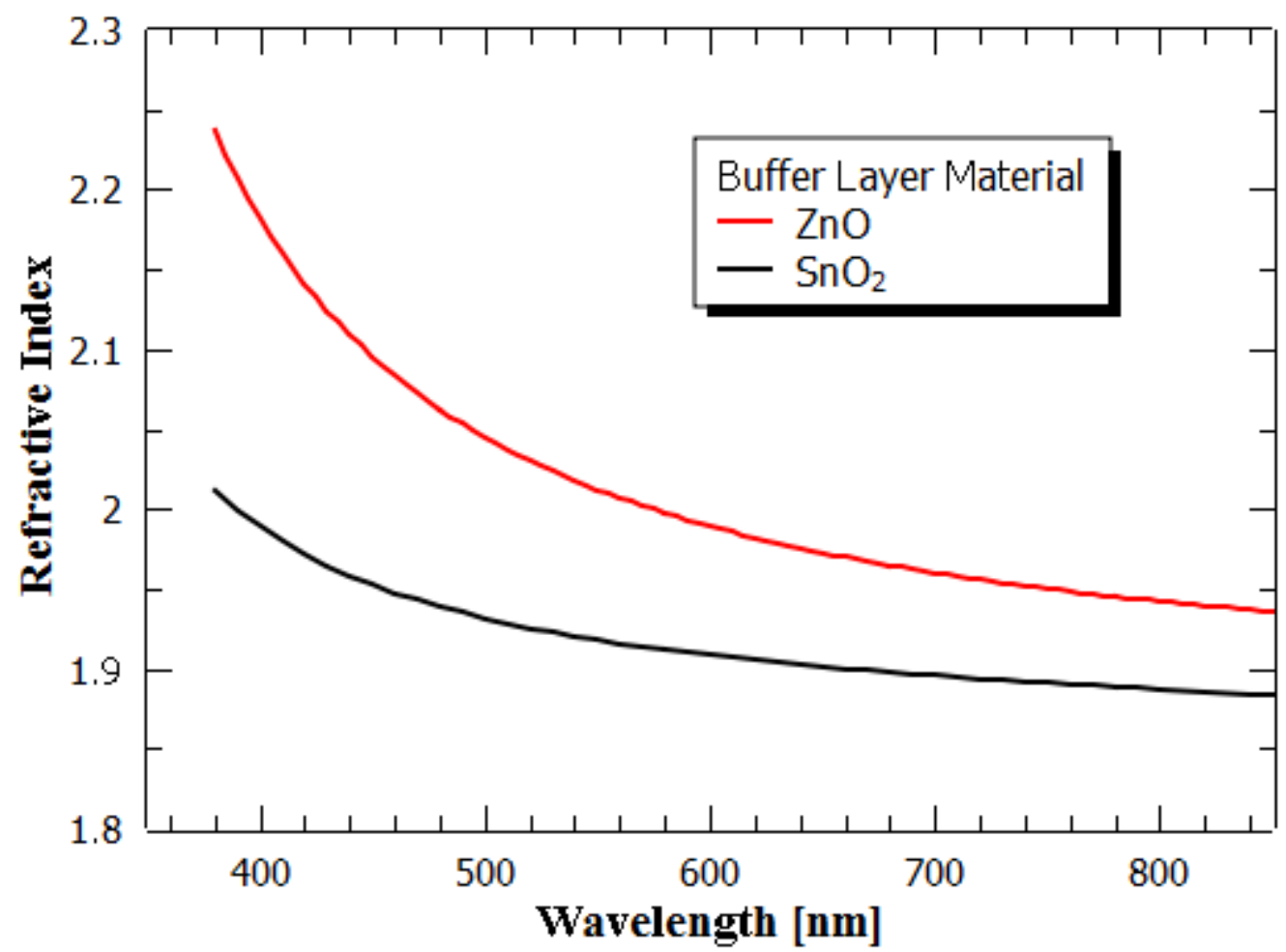

Figure 2 The refractive index dispersion for $\mathrm{SnO}_{2}$ and $\mathrm{ZnO}$, the candidate high resistance buffer layer materials. 


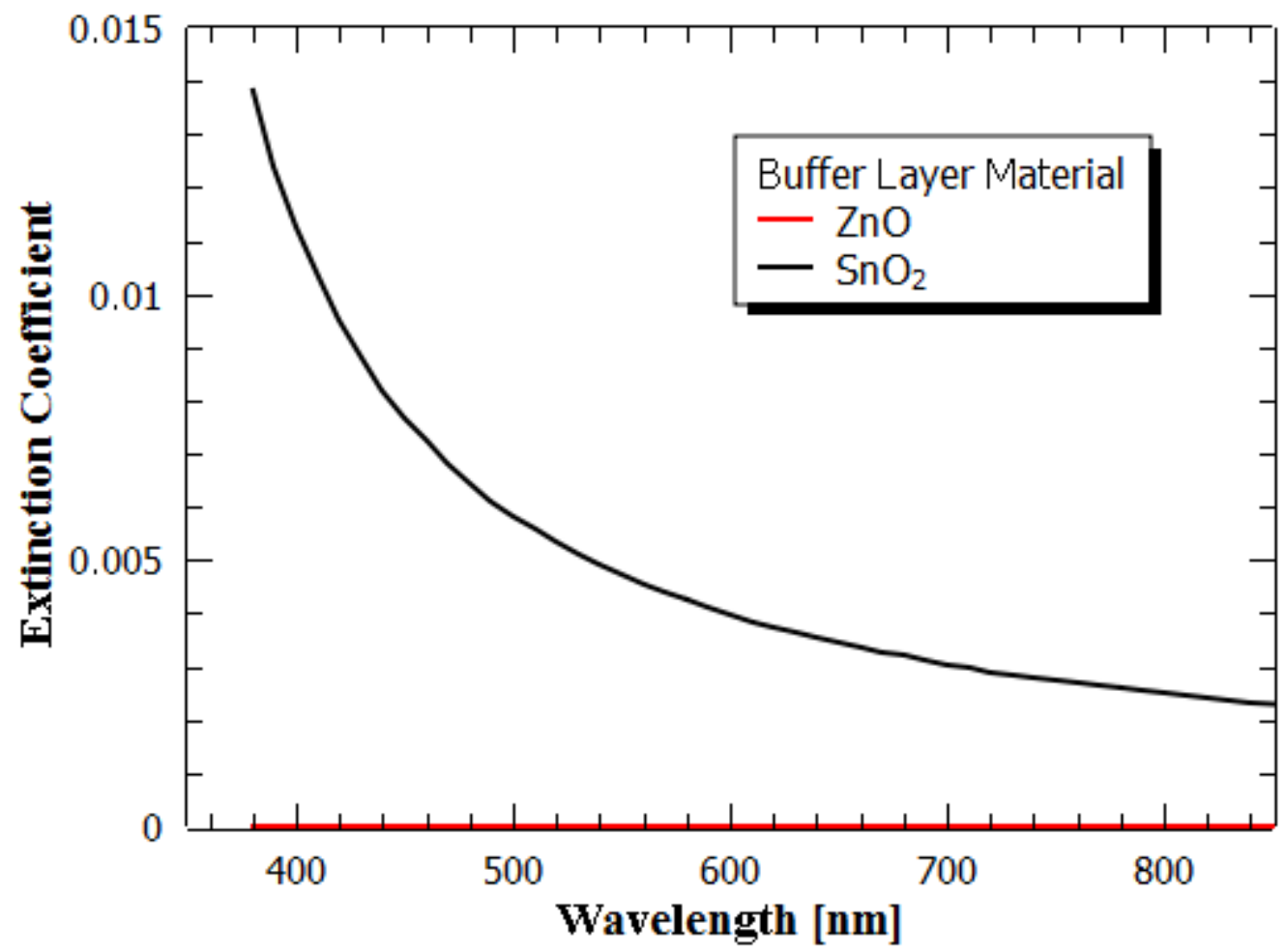

Figure 3 The extinction coefficients of $\mathrm{SnO}_{2}$ and $\mathrm{ZnO}$, the candidate high resistance buffer layer materials.

\section{Optical modeling}

The thin film CdTe solar cell was modeled and optimized for maximum light transmission to the CdTe layer, using software based on the transfer matrix method [21]. The performance of the solar cells was assessed by calculating the weighted average transmission (WAT) of light into the CdTe absorber in the 350nm - 850nm spectral range, by incorporating the photon flux in the AM1.5g solar spectrum (Ф) [22].

$$
W A T\left(\lambda_{\max }, \lambda_{\min }\right)=\frac{\int_{\lambda_{\min }}^{\lambda_{\max }} \Phi \cdot T d \lambda}{\int_{\lambda_{\min }}^{\lambda_{\max }} T d \lambda}
$$

Initially, a simple solar cell consisting of TEC10 substrate with a CdS (thickness 50nm - 300nm) and CdTe junction was modeled for comparison. Complete light absorption in the CdTe layer was assumed. Such devices can usually achieve $\sim 12 \%$ conversion efficiency with a photocurrent of $22 \mathrm{~mA} / \mathrm{cm}^{2}$ [2], [4]. The effect of the addition of a HRT buffer layer on the optical performance was then modeled. Because thicknesses below 50nm are not electrically viable, the buffer layer materials initially were investigated 
at thicknesses in the range $50 \mathrm{~nm}$ to $500 \mathrm{~nm}$. However, low thickness HRT buffer layer interference effects were investigated at select thicknesses of CdS, despite being electronically unsuitable. TEC 10 glass has a sheet of fluorine doped tin oxide (FTO) with a sheet resistance of $9 \Omega / \square$ and a thickness of 350nm. Therefore, to create an accurate model of a possible CdTe cell design the TCO layer was modeled as a FTO layer at a thickness of 350nm.

The refractive index and extinction coefficient data for $\mathrm{CdS}$ and $\mathrm{SnO}_{2}$ were measured using a Horiba, Jobin Yvon, UVISEL Spectroscopic ellipsometer. The refractive index and extinction coefficient for $\mathrm{ZnO}$ was obtained from Sun and Kwok [23]. The refractive index and extinction coefficient values for CdTe were taken from the Handbook of the Optical Constants of Solids I [24].

\section{Results}

\subsubsection{Varying the thickness of the CdS layer}

The effect of modeling the variation in the thickness of the CdS layer was investigated. The effect of varying thickness was first modeled in a stack without a HRT buffer layer. The results are shown in figure 4. The CdS thickness reduces light transmittance to the CdTe layer at all thicknesses. The thin film $\mathrm{CdS}$ is usually between $50 \mathrm{~nm}$ and $150 \mathrm{~nm}$ thick in CdTe devices [25]. Figure 4 shows that the optical transmission is highly sensitive to the thickness of the CdS layer. Transmittance is $77.9 \%$ at $50 \mathrm{~nm}$ thickness, but at 300nm it reduces dramatically to $59.4 \%$. 


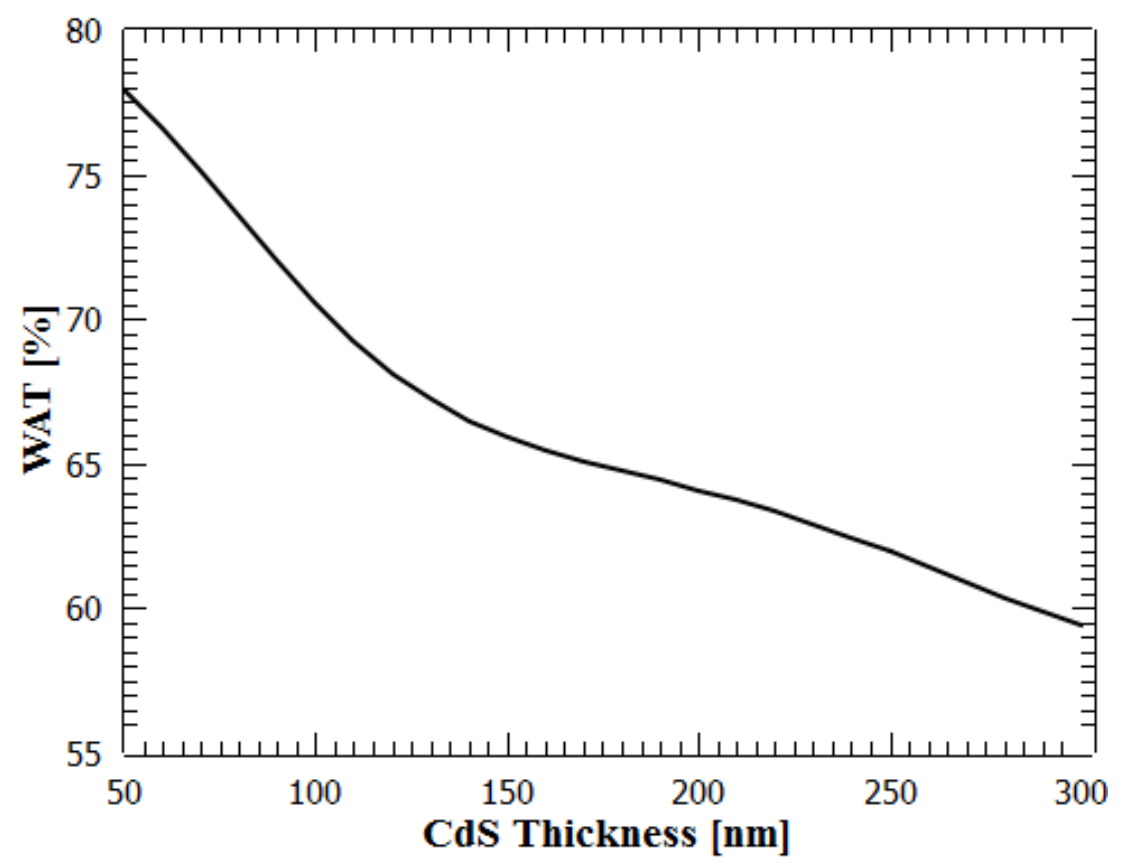

Figure 4 The modeled optical weighted average transmission (WAT) to the CdTe layer in a CdTe photovoltaic device, plotted against the thickness of the CdS layer. The effect of a high resistance buffer layer is not included.

\subsubsection{Varying the thickness of the $\mathrm{SnO}_{2}$ High Resistance Transparent buffer layer}

The effect of a $\mathrm{SnO}_{2} \mathrm{HRT}$ buffer layer on transmittance was calculated by varying the thickness of the $\mathrm{CdS}$ layer between $50 \mathrm{~nm}$ and $300 \mathrm{~nm}$ at $10 \mathrm{~nm}$ intervals, and by varying the thickness of the $\mathrm{SnO}_{2}$ layer up to $500 \mathrm{~nm}$ at $10 \mathrm{~nm}$ intervals. The optical transmission into the active layer was calculated at each point and a $3 \mathrm{D}$ grid was generated from the data. The $3 \mathrm{D}$ plot is shown in figure 5.

A maximum transmittance at a $\mathrm{CdS}$ thickness of $50 \mathrm{~nm}$ was calculated to be $78.0 \%$ at a $\mathrm{SnO} 2$ layer thickness of $50 \mathrm{~nm}$. At thicknesses greater than $70 \mathrm{~nm}$ the absorbing properties of $\mathrm{SnO}_{2}$ become more influential and the transmission to the absorber is reduced. Reducing the thickness of the CdS layer to below 50nm increases the transmittance. However, CdS thicknesses below 50nm have not been considered since layers this thin are likely to be discontinuous and lead to shorting of the cell [26]. 


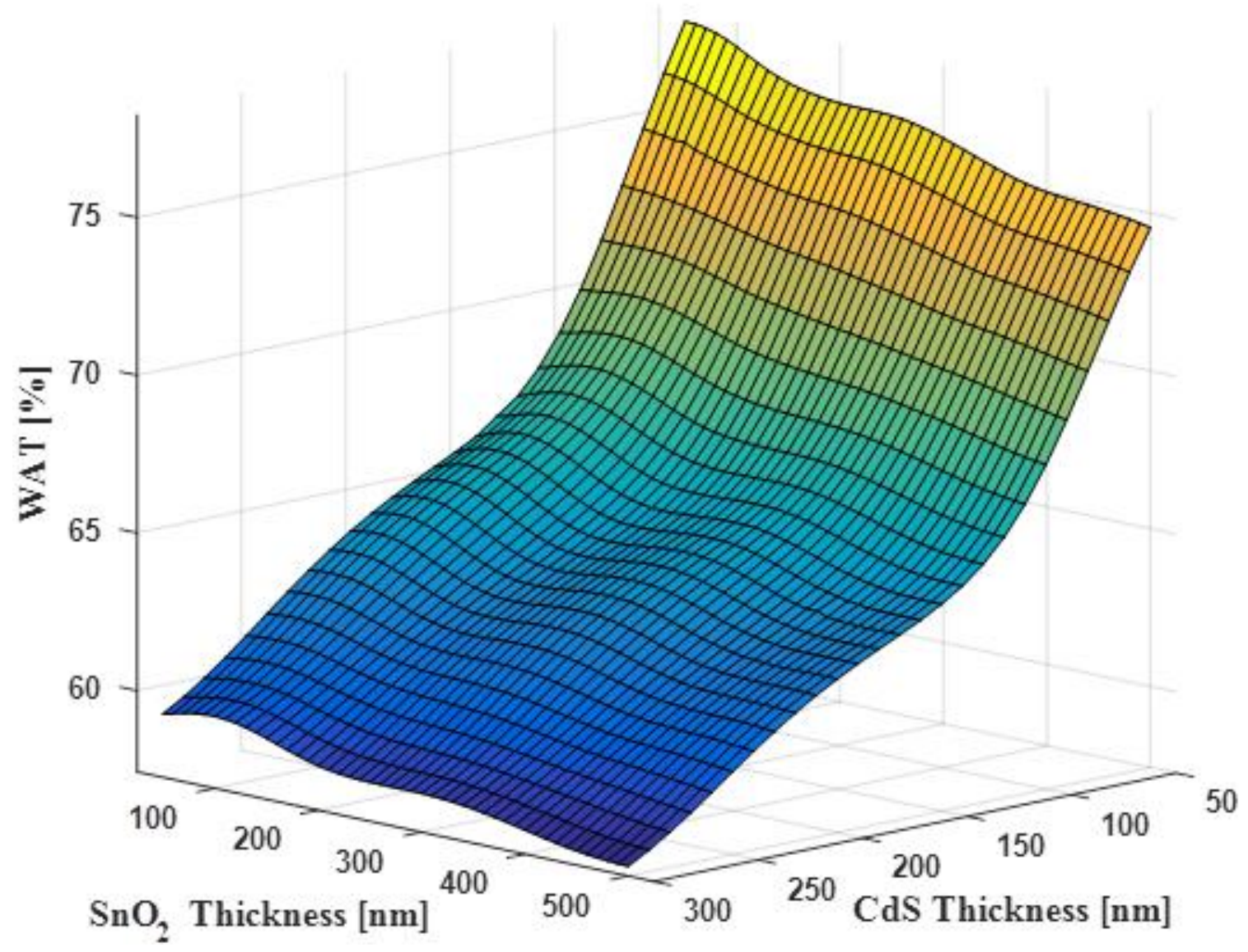

Figure 5 The modeled WAT to the absorbing layer of a CdTe solar cell as a function of CdS and the $\mathrm{SnO}_{2}$ layer thickness. Thicknesses of $\mathrm{CdS}$ and $\mathrm{SnO} 2$ layers $(\mathrm{nm})$ are plotted on the $\mathrm{X}-\mathrm{Y}$ plane and the modeled value for WAT is plotted along the Z-axis. In this region a maximum transmission occurs at 50nm CdS and 48nm $\mathrm{SnO}_{2}$.

In practice, it is important to be aware of the effect of thickness tolerance on transmission. It is possible to achieve thickness accuracy, using time control, of $+/-2 \%$ with magnetron sputtering. Evaporation (thermal or electron beam) can be achieved with similar accuracy using quartz crystal control. Varying the thickness of the CdS and HRT buffer layer around the transmission maximum by $1 \mathrm{~nm}$ (a variation of $+/-2 \%$ ) results in an insignificant relative loss of $0.002 \%$ transmittance. This illustrates the sensitivity of transmission on layer thickness and also confirms that transmission is most sensitive to the CdS layer thickness. The dependence is predominantly flat, indicating that although there is an interference effect, it is not significant in terms of device design. The use of a $\mathrm{SnO}_{2} \mathrm{HRT}$ buffer layer is dictated more on its effect on Voc than any increase in transmission caused by engineering layer thicknesses. 
3.1.3. Varying the thickness of the $\mathrm{ZnO}$ High Resistance Transparent buffer layer

The thickness of the CdS layer was again varied between 50nm and 300nm at $10 \mathrm{~nm}$ intervals and the $\mathrm{ZnO}$ HRT buffer layer thickness was varied between $50 \mathrm{~nm}$ and $500 \mathrm{~nm}$ at $10 \mathrm{~nm}$ intervals. A value for transmission to the active layer was calculated at each point and a 3D grid was generated from the data. The 3D plot in figure 6 shows how the use of $\mathrm{ZnO}$ as a buffer layer results in more significant interference effects. These effects maintain the transmission nearly level across all thicknesses of $\mathrm{ZnO}$. Only a slight decrease in transmission is observed as the $\mathrm{ZnO}$ layer thickness is increased. It is also shown that, as with a $\mathrm{SnO}_{2} \mathrm{HRT}$ buffer, the CdS thickness has the greatest effect on transmission to the absorber when a $\mathrm{ZnO}$ HRT buffer is used.

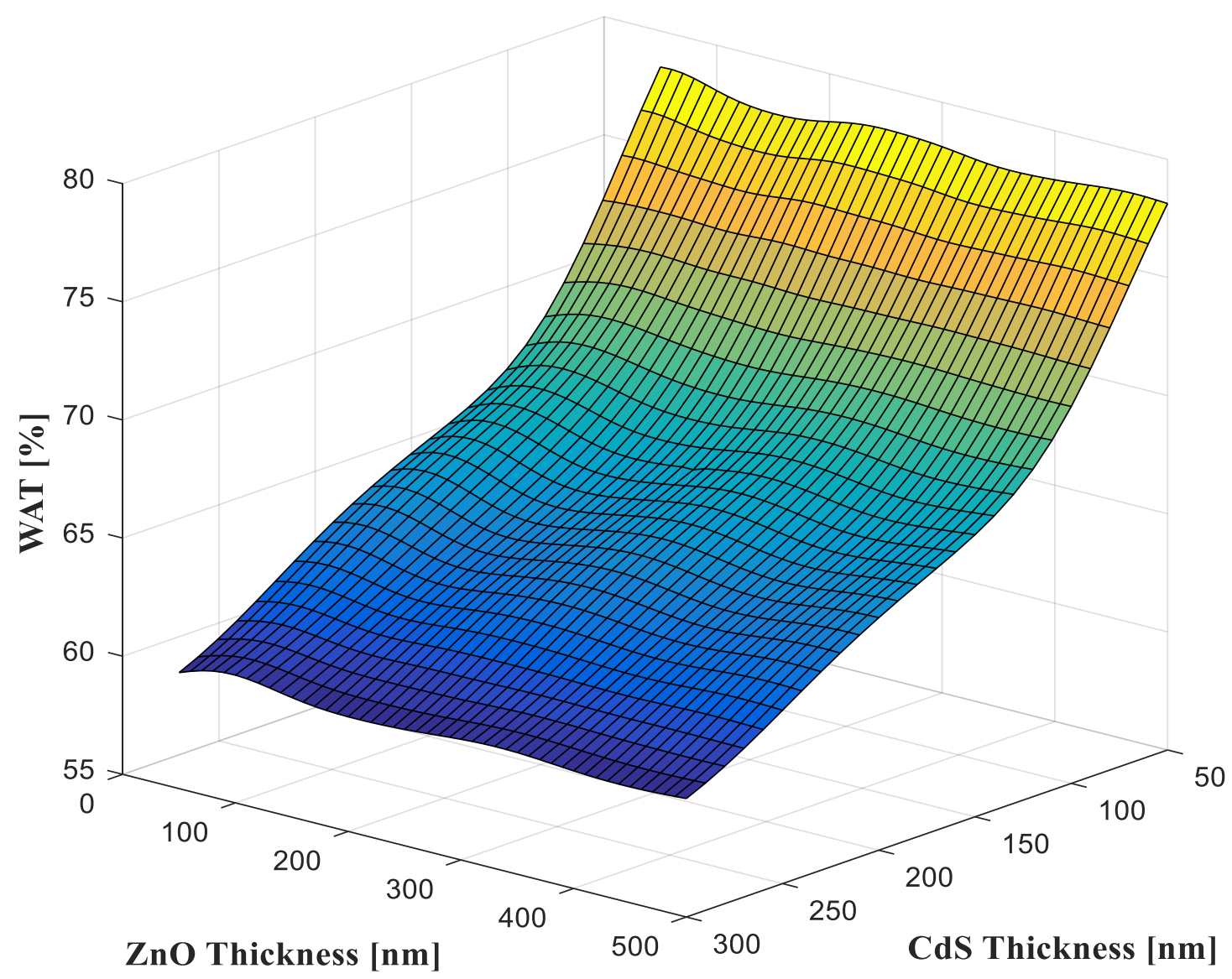

Figure 6 The modeled WAT to the absorber layer for a CdTe solar cell with CdS window and a $\mathrm{ZnO}$ high resistance buffer layer. The thickness of the $\mathrm{CdS}$ and $\mathrm{ZnO}$ layers $(\mathrm{nm})$ are plotted on the $\mathrm{X}-\mathrm{Y}$ plane and the modeled value for WAT is plotted along the Z-axis. 
In general, the addition of a ZnO HRT buffer layer improves light transmission to the absorbing layer, with interference effects resulting in maximum transmission occurring at non-zero thicknesses. Interference effects result in maxima in transmittance at different thicknesses of $\mathrm{ZnO}$ at each thickness of the $\mathrm{CdS}$ layer. The $\mathrm{ZnO}$ layer does not suffer from significant absorption losses as occurs with $\mathrm{SnO}_{2}$, and therefore thicker HRT buffer layers can be used without significant losses.

A maximum transmittance at a $\mathrm{CdS}$ thickness of $50 \mathrm{~nm}$ was calculated to be $78.5 \%$ at a $\mathrm{ZnO}$ thickness of $58 \mathrm{~nm}$. As with a $\mathrm{SnO}_{2} \mathrm{HRT}$ buffer layer, transmission values can be greater at CdS thicknesses less than 50nm due to the absorbing effect of the $\mathrm{CdS}$ layer, but these are disregarded as they are not considered practical. As with $\mathrm{SnO}_{2}$, variation of $+/-2 \%$ in $\mathrm{ZnO}$ layer thicknesses results in an insignificant relative loss of $0.002 \%$. Therefore, the accuracy of layer thickness control during deposition is achievable with magnetron sputtering or evaporation techniques allied with quartz crystal monitoring.

The addition of a ZnO HRT buffer layer is beneficial to transmission at both 50nm and 100nm CdS thicknesses. The benefits are still present at $\mathrm{ZnO}$ thicknesses greater than $100 \mathrm{~nm}$, but interference effect maxima occur at different thicknesses of $\mathrm{ZnO}$ depending on the thickness of $\mathrm{CdS}$. Consequently, a HRT buffer layer thickness that is beneficial at a CdS thickness of $100 \mathrm{~nm}$ might be slightly detrimental or relatively less effective at a CdS thickness of 50nm.

3.1.4. A comparison of the optical effects of introducing $\mathrm{SnO} 2$ and $\mathrm{ZnO}$ high resistance buffer layers

A direct comparison of transmission to the absorbing layer with a $\mathrm{ZnO} \mathrm{HRT}$ layer and a $\mathrm{SnO}_{2} \mathrm{HRT}$ layer is provided in figure 7. Although buffer layer thicknesses below 50nm are usually unsuitable, for clarity figure 8 draws out the comparison of the 2 candidate HRT buffer layer materials, highlighting the effect of interference when using thin layers. The HRT buffer layer materials are compared at two CdS layer thicknesses often used in devices, $50 \mathrm{~nm}$ and $100 \mathrm{~nm}$. The comparison shows that the use of $\mathrm{ZnO}$ as a HRT buffer layer results in a greater transmission to the CdTe absorber, regardless of the respective thickness of the HRT buffer layer and the CdS layer. The use of $\mathrm{SnO}_{2}$ is optically beneficial only at certain layer thicknesses. 


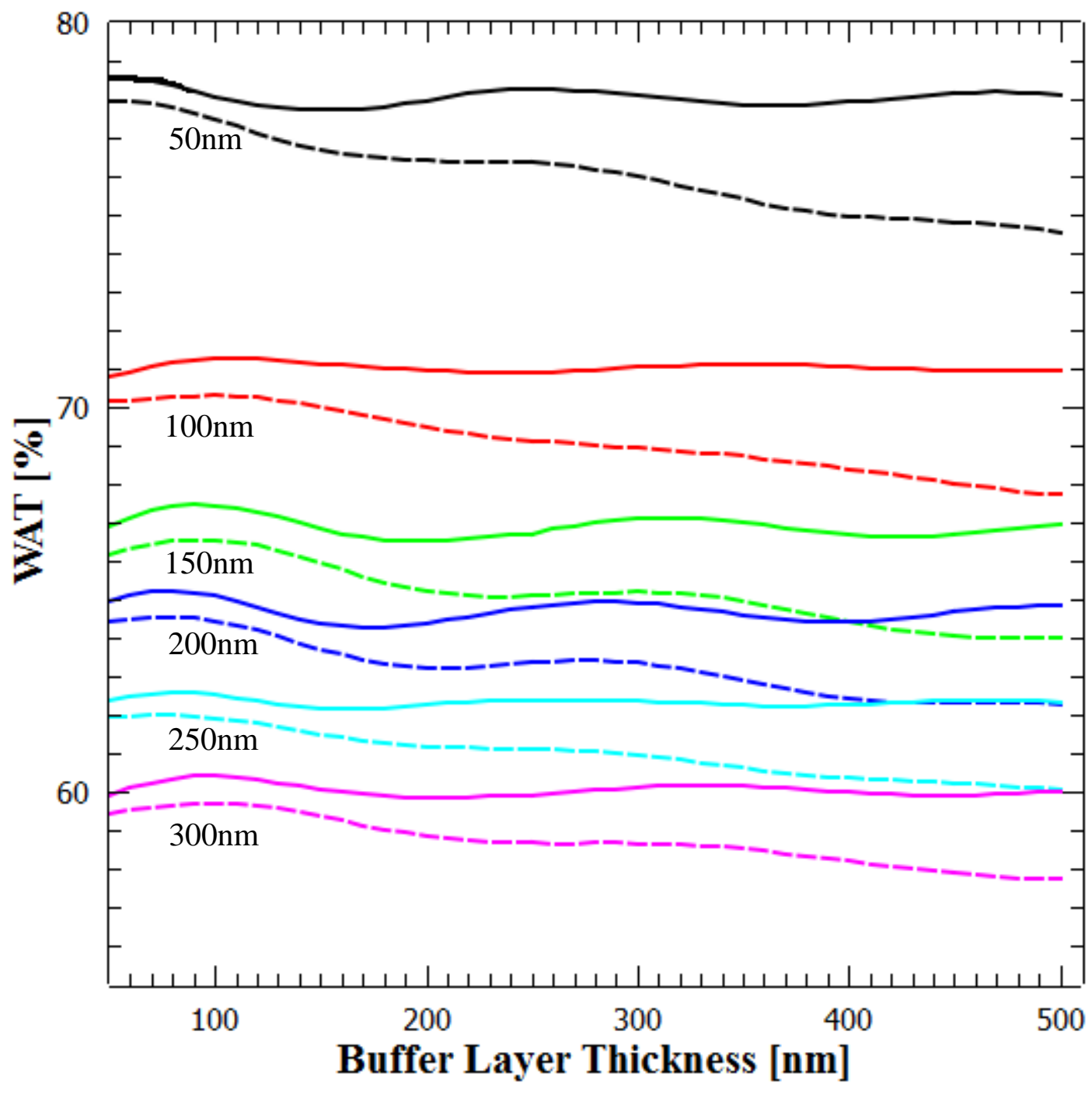

Figure 7 Modeled WAT to the absorber layer of the CdTe stack plotted against thickness for the two candidate HRT layers. $\mathrm{ZnO}$ data is represented by solid lines and $\mathrm{SnO} 2$ data is represented by dashed lines. Values are given at selected thicknesses of CdS layer; 50, 100, 150, 200, 250 and 300nm. 


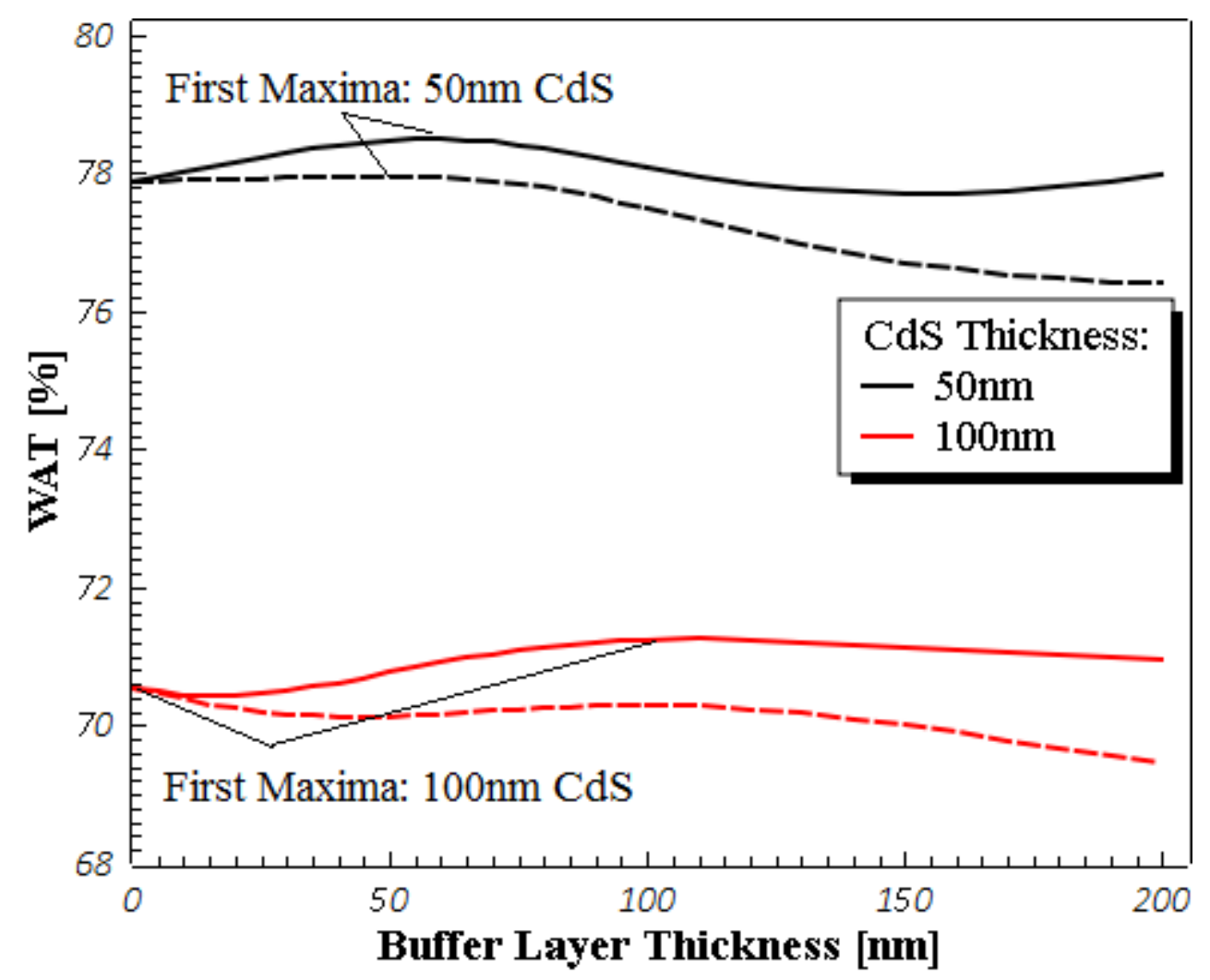

Figure 8 Comparison of modeled WAT to the CdTe layer in the solar cell plotted against the thickness of the $\mathrm{ZnO}$ and $\mathrm{SnO}_{2}$ buffer layers. The $\mathrm{ZnO}$ data is represented by solid lines and $\mathrm{SnO} 2$ data is represented by dashed lines. Values are given at selected thicknesses of CdS layer; 50nm and 100nm.

\section{Conclusions}

Table 1 provides a comparison of the optimization of the optical effects using a $\mathrm{SnO}_{2}$ or $\mathrm{ZnO}$ high resistance transparent buffer layer above the transparent conductor in a thin film CdTe device. Optical interference occurs in the multilayer thin film stack design structure used in thin film CdTe photovoltaic devices. It also occurs in other thin film device structures such as CIGS, CZTS, amorphous Silicon, and perovskite solar cells. It is important to optimize layer thicknesses within the stack to engineer maximum light transmission to the absorber layer so that the highest possible photocurrent is produced. In order to achieve the thickness tolerance required in these optically active layers, control of the deposition rate is key to this process. When considering only optical effects, thickness control in the absorber layer is unimportant once complete absorption is achieved. 
Table 1 Comparison of HRT layer performance

\begin{tabular}{lll}
\hline & ZnO & SnO2 \\
\hline Maximum WAT (CdS 50nm) & $78.5 \%$ & $78.0 \%$ \\
$\begin{array}{l}\text { Buffer layer thickness at maximum WAT } \\
\text { (optimum) }\end{array}$ & $58 \mathrm{~nm}$ & $48 \mathrm{~nm}$ \\
$\begin{array}{l}\text { WAT at buffer layer 50nm } \\
\text { thickness (CdS50nm) }\end{array}$ & $78.5 \%$ & $78.0 \%$ \\
$\begin{array}{l}\text { Absolute transmission gain at optimum HRT } \\
\text { layer thickness compared to no buffer layer at }\end{array}$ & $0.6 \%$ & $0.1 \%$ \\
$\begin{array}{l}\text { 50nm CdS } \\
\text { Relative maximum transmission loss due to a } \\
+/-2 \% \quad 0.002 \%\end{array}$ & $0002 \%$ \\
transmission & & \\
\hline
\end{tabular}

The maximum transmission possible using a $\mathrm{SnO}_{2}$ HRT buffer layer was calculated to occur with $50 \mathrm{~nm}$ of $\mathrm{CdS}$ and $48 \mathrm{~nm}$ of $\mathrm{SnO}_{2}$. At these values, the beneficial interference effects of incorporating a $\mathrm{SnO}_{2}$ layer increases transmission and outweighs the absorption effects within the $\mathrm{SnO}_{2}$ layer. The transmission gained by optimising HRT and CdS layer thicknesses would lead to a gain in photocurrent of $0.6 \%$ for $\mathrm{ZnO}$ and $0.1 \%$ for $\mathrm{SnO}_{2}$. Incorporation of the optimized $\mathrm{SnO}_{2}$ layer leads to a maximum weighted average transmission (WAT) of $78.0 \%$. Varying the thickness of the HRT and CdS layers around maximum transmission by $+/-2 \%$, results in an insignificant transmittance loss of $0.002 \%$. This tolerance is achievable by using magnetron sputtering, or thermal/electron beam evaporation using quartz crystal control.

The maximum WAT of $78.5 \%$, using a $\mathrm{ZnO}$ buffer layer with a $50 \mathrm{~nm} \mathrm{CdS}$ layer, was calculated to occur using a thickness of $58 \mathrm{~nm}$. Therefore it is possible to use a thicker HRT layer for $\mathrm{ZnO}$ than $\mathrm{SnO}_{2}$ which could have electrical benefits. Varying thickness of a ZnO HRT layer around maximum transmission by $+/-2 \%$ also resulted in negligible losses, similar to those calculated for $\mathrm{SnO}_{2}(0.002 \%)$. However, testing a layer thickness tolerance of $+/-5 \mathrm{~nm}(\sim+/-10 \%)$ resulted in an absolute WAT loss of $1 \%$, which is significant. Therefore, layer thickness control is important.

The anti-reflection properties of a $\mathrm{ZnO}$ HRT layer are more pronounced than those for the $\mathrm{SnO}_{2} \mathrm{HRT}$ layer. This is due to better refractive index matching between the HRT layer, the window layer, and the 
TCO. Moreover, the ZnO HRT layer has low absorption losses, so the interference effect can be exploited at greater thickness to minimize the reflection losses.

The work presented in this paper has shown that the use of a ZnO HRT buffer generally results in a higher WAT than $\mathrm{SnO}_{2}$ at all layer thicknesses. The maximum WAT transmission achievable is $78.5 \%$ which is $0.5 \%$ greater than the maximum achievable with $\mathrm{SnO}_{2}$. $\mathrm{ZnO}$ also has a greater maximum transmission at $58 \mathrm{~nm}$ thickness compared to $\mathrm{SnO}_{2}$ at $48 \mathrm{~nm}$ thickness. The layer thickness of $\mathrm{ZnO}$ can be increased while still retaining increases in transmission. This is important in practice because one of the benefits of incorporating a high resistance layer is the prevention of shorting. This is more likely to be successful as the thickness of the high resistance layer increases.

The application of a multilayer anti-reflection coating has been shown to further increase the transmission to the active layer by reducing reflection from the glass-air interface by 70\% [22], [27]. Optical modeling has shown that the use of a broadband anti-reflection coating at the glass-air interface has a negligible effect on the optimization of the thicknesses of layers in the CdTe thin film device.

It should be recognized that this paper has considered only optical interference effects to maximize light transmission to the absorber layer, thereby maximising the current density. Electrical benefits also accrue from the insertion of a high resistance transparent buffer layer which increases Voc. Consequently, the choice of material will be influenced by a combination of optical and electrical effects.

\section{Acknowledgements}

The authors are grateful to UKERC for funding this work through the EPSRC Supergen SuperSolar Hub. One of the authors (GW) is grateful to Loughborough University Graduate School and NSIRC Ltd for supporting a CASE studentship.

\section{References}

[1] M. A. Green, K. Emery, Y. Hishikawa, W. Warta, and E. D. Dunlop, "Solar cell efficiency tables (version 48)," Prog. Photovolt Res. Appl., vol. 24, no. May 2016, pp. 905-913, 2016. 
[2] A. Morales-Acevedo, "Thin film CdS/CdTe solar cells: Research perspectives," Sol. Energy, vol. 80, no. 6, pp. 675-681, 2006.

[3] J. Britt and C. Ferekides, "Thin-film CdS/CdTe solar cell with 15.8\% efficiency," Appl. Phys. Lett., vol. 62, no. 22, pp. 2851-2852, 1993.

[4] Z. Ma, J. McCamy, J. M. Kephart, R. M. Geisthardt, W. S. Sampath, V. V Plotnikov, and A. Compaan, "Superstrate design for increased $\mathrm{CdS} / \mathrm{CdTe}$ solar cell efficiencies," in Conference Record of the IEEE Photovoltaic Specialists Conference, 2013, no. c, pp. 1150-1155.

[5] L. A. Kosyachenko, E. V Grushko, and X. Mathew, "Quantitative assessment of optical losses in thin-film CdS / CdTe solar cells,” Sol. Energy Mater. Sol. Cells, vol. 96, pp. 231-237, 2012.

[6] B. Sopori, J. Madjdpour, Y. Zhang, W. Chen, S. Guha, J. Yang, and A. Banerjee, "Optical Modeling of a-Si Solar Cells,” no. November, 1999.

[7] Pilkington Group Limited, “Global Glass Handbook 2012 Architectural Products,” 2012.

[8] J. M. Kephart, R. M. Geisthardt, and W. S. Sampath, "Optimization of CdTe thin-film solar cell efficiency using a sputtered, oxygenated CdS window layer," Prog. Photovolt Res. Appl., vol. 23, no. January 2015, pp. 1484-1492, 2015.

[9] X. Wu, R. G. Dhere, Y. Yan, M. J. Romero, Y. Zhang, J. Zhou, C. DeHart, a Duda, C. Perkins, and B. To, "High-efficiency polycrystalline CdTe thin-film solar cells with an oxygenated amorphous CdS (a-CdS:O) window layer," Conf. Rec. IEEE Photovolt. Spec. Conf., no. May, pp. 531-534, 2002.

[10] M. Rubin, “Optical properties of soda lime silica glasses,” Sol. Energy Mater., vol. 12, no. 4, pp. 275-288, 1985.

[11] K.-H. Kim and Q-Han Park, "Perfect anti-reflection from first principles," Sci. Rep., vol. 3, pp. 1$5,2013$.

[12] J. F. Jordan, "Photovoltaic cell and method.” Google Patents, 1993. 
[13] C. S. Ferekides, U. Balasubramanian, R. Mamazza, V. Viswanathan, H. Zhao, and D. L. Morel, “CdTe thin film solar cells: Device and technology issues,” Sol. Energy, vol. 77, no. 6, pp. 823830, 2004.

[14] Z. M. Jarzebski and J. P. Marton, "Physical Properties of SnO2 Materials I. Preparation and Defect Structure,” J. Electrochem. Soc., vol. 123, no. 7, pp. 199-205, 1976.

[15] Y. Wang, I. Ramos, and J. J. Santiago-Aviĺs, "Optical bandgap and photoconductance of electrospun tin oxide nanofibers," J. Appl. Phys., vol. 102, no. 9, 2007.

[16] C. S. Ferekides, R. Mamazza, U. Balasubramanian, and D. L. Morel, "Transparent conductors and buffer layers for CdTe solar cells,” Thin Solid Films, vol. 480-481, pp. 224-229, 2005.

[17] a. Ismail and M. J. Abdullah, "The structural and optical properties of $\mathrm{ZnO}$ thin films prepared at different RF sputtering power," J. King Saud Univ. - Sci., vol. 25, no. 3, pp. 209-215, 2013.

[18] R. E. Treharne, a Seymour-Pierce, K. Durose, K. Hutchings, S. Roncallo, and D. Lane, “Optical Design and Fabrication of Fully Sputtered CdTe/CdS Solar Cells,” J. Phys. Conf. Ser., vol. 286, p. 012038, 2011.

[19] X. Wu, R. G. Dhere, D. S. Albin, T. a Gessert, C. Dehart, J. C. Keane, a Duda, T. J. Coutts, S. Asher, D. H. Levi, H. R. Moutinho, Y. Yan, T. Moriarty, S. Johnston, K. Emery, and P. Sheldon, “High-Efficiency CTO / ZTO / CdS / CdTe Polycrystalline Thin-Film Solar Cells," NCPV Progr. Rev. Meet., no. October, 2001.

[20] S. Chaisitsak, T. Sugiyama, a. Yamada, and M. Konagai, "Cu (InGa) Se2 Thin-film Solar Cells with High Resistivity ZnO Buffer Layers Deposited by Atomic Layer Deposition.,” Jpn. J. Appl. Phys, vol. 38, no. 9, pp. 4989-4992, 1999.

[21] A. Macleod and C. Clark, Optical Coating Design with the Essential Macleod. Thin Film Center Inc Tucson, 2012.

[22] P. M. Kaminski, G. Womack, and J. M. Walls, "Broadband Anti-Reflection coatings for Thin 
Film Photovoltaics," in 40th IEEE PVSC, 2014, pp. 2778-2783.

[23] X. W. Sun and H. S. Kwok, "Optical properties of epitaxially grown zinc oxide films on sapphire by pulsed laser deposition,” J. Appl. Phys., vol. 86, no. 1, pp. 408-411, 1999.

[24] E. D. Palik, Handbook of the Optical Constants of Solids I., 1st ed. London: Academic Press, 1985.

[25] K. Durose, P. R. Edwards, and D. P. Halliday, "Materials aspects of CdTe/CdS solar cells," J. Cryst. Growth, vol. 197, no. 3, pp. 733-742, 1999.

[26] X. Wu, P. Sheldon, Y. Mahathongdy, R. Ribelin, a Mason, H. R. Moutinho, and T. J. Coutts, “CdS/CdTe thin-film solar cell with a zinc stannate buffer layer," Aip Conf. Proc., no. October, pp. $37-41,1999$.

[27] P. M. Kaminski, F. Lisco, and J. M. Walls, "Multilayer Broadband Antireflective Coatings for More Efficient Thin Film CdTe Solar Cells," IEEE J. Photovoltaics, vol. 4, no. 1, pp. 452-456, Jan. 2014. 